\title{
Penyadapan dalam Hukum Internasional dan Implikasinya terhadap Hubungan Diplomatik Indonesia dengan Australia
}

\author{
Jawahir Thontowi \\ Fakultas Hukum Universitas Islam Indonesia \\ Jln. Tamansiswa No. 158 Yogyakarta \\ impress_jawahir@yahoo.com
}

\begin{abstract}
The first and foremost issue in this study is the general principles and legal arrangements of tapping into national and international human rights law. Second, as lex specially can tappin be prosecuted to national or international law? Third, why is the wiretapping of Australia against Indonesia not considered as a crime but a violation of the diplomatic code of conduct. This is a normative research. The study reveals that first: legally tapping is prohibited by law and international human rights based on the Universal Declaration of Human Rights (UDHR) in 1948, the International Covenant on Civil and Political Rights (ICCPR) in 1966, the European Convention for the Protection of Human Rights and Fundamental Freedoms (1958) and the 1961 Vienna Convention. While in the national law, the prohibition of tapping is provided in Article 28G paragraph (1) of the 1945 Constitution, Article 32 of law No. 39 of 1999, Article 40 of Law No. 36 of 1999, Article 31 paragraph (1) of Law No. 11 of 2008, and Article 31 paragraph (2) of Law No. 11 Year 2008. Tapping is allowed when the order and security of the country is being threatened as stipulated in the Law on Combating Criminal Acts of Terrorism, Narcotics Law, the Law on the Corruption Eradication Commission, and the Law on State Intelligence. Second, the ban on wiretapping in international criminal law can be excluded for particular crimes as stipulated by Rome Statute of 1998, and Transnational Organized Crime. Thirdly, in the context of the behavior relations between countries, Australia tapping against Indonesia has shifted meaning from a crime into a violation of the diplomatic code of conduct. Indonesia acted diplomatically towards Australia's violation by forgiveness.
\end{abstract}

Keywords :Tapping, violation of the code, the individual rights

\begin{abstract}
Abstrak
Adapun permasalahan dalam penelitian ini: pertama, prinsip-prinsip umum dan pengaturan hukum penyadapan dalam hukum HAM nasional dan internasional. Kedua, penyadapan sebagai lex special tidak dapat dituntut hukum nasional maupun internasional? Ketiga, tindakan penyadapan Australia terhadap Indonesia bukan sebagai kejahatan melainkan pelanggaran kode etik diplomasi. Metode penelitian yang digunakan dalam penelitian ini adalah normatif. Hasil penelitian menyimpulkan, pertama: secara yuridis penyadapan dilarang dalam hukum dan HAM internasional berdasarkan Universal Declaration of Human Right (UDHR) 1948, International Covenant on Civil and Political Right (ICCPR) 1966, Konvensi Eropa untuk perlindungan HAM dan Kebebasan Fundamental (1958) dan Konvensi Wina 1961. Sedangkan dalam hukum nasional, larangan penyadapan diatur dalam Pasal 28G ayat (1) UUD 1945, Pasal 32 UU No. 39 Tahun 1999, Pasal 40 UU No 36 Tahun 1999, Pasal 31 ayat (1) UU No. 11 Tahun 2008, dan Pasal 31 ayat (2) UU No. 11 Tahun 2008. Aksi penyadapan diperbolehkan pada suatu keadaan mengancam ketertiban dan keamanan negara sebagaimana diatur dalam UU Pemberantasan Tindak Pidana Terorisme, UU Narkotika, UU Komisi Pemberantasan Tindak Pidana Korupsi, dan UU Intelijen Negara. Kedua, larangan penyadapan dalam hukum pidana internasional bisa diperkecualikan untuk khususnya kejahatan sebagaimana diatur Statuta Roma 1998, dan Kejahatan Lintas Negara Teroganisir. Ketiga, dalam konteks perilaku hubungan antara negara, penyadapan yang dilakukan Australia terhadap Indonesia telah bergeser makna tidak lagi sebagai kejahatan melainkan lebih merupakan pelanggaran kode etik diplomatik. Sikap Indonesia terhadap Australia dituangkan dalam sikap diplomasi berupa pemaafan.
\end{abstract}

Kata kunci: Hak atas privasi, penyadapan, gangguan. 


\section{Pendahuluan}

Isu tentang penyadapan sering muncul dalam perdebatan politik maupun hukum di kalangan para politisi atau para penegak hukum serta akademisi di Indonesia akhir-akhir ini. Penyadapan setidaknya telah dianggap sebagai alat ampuh yang diharapkan mampu menguak atau setidaknya membuka tabir akan adanya kejahatan yang terorganisir dan juga menurut beberapa kalangan dapat mencegah adanya kejahatan terhadap keamanan negara (national security). Namun, penyadapan juga digunakan oleh pihak-pihak tertentu untuk hal-hal negatif yang berpotensi merugikan pihak korban. Bahkan pada perkembangannya yang disadap bukan hanya informasi terkait kepentingan pribadi perorangan, karena saat ini informasi-informasi rahasia sebuah negara juga bisa menjadi obyek penyadapan. Semakin canggihnya perkembangan dunia intelejen menuntut agenagen diplomatik setiap negara untuk lebih berhati-hati dalam bersikap dan bertindak untuk menjaga keharmonisan hubungan antar negara.

Ada beberapa isu menarik yang mendorong perlunya dilakukan kajian tentang penyadapan. Pertama, kedaulatan negara Indonesia terusik ketika Tony Abbot tidak mau menyampaikan pernyataan permohonan maaf sebagaimana dituntut sebagian besar masyarakat Indonesian karena beberapa telpon pejabat Indonesia 2009 disadap oleh Intelejen Australia. Dalam Sydeny Herald Morning, dikemukakan bahwa menjelang Pemilihan Presiden SBY kedua kali 2009, Handphone ibu Any Yudhoyono, Kementerian Ekonomi Hatta Rajasa, dan juga Menteri Pertahanan, Jendral Djoko, telah dilakukan penyadapan oleh staf Intelejen Australia. Berita tersebut diketahui setelah Edward Snowden, seorang mantan staf intelejen CIA AS membocorkan berbagai jaringan teknologi informasi, AS menyadap negara-negara di Eropa, termasuk beberapa negara di Asia Tenggara. Akibatnya, Presiden SBY menarik sementara Duta Besar Indonesia dari Canberra dan mebatalkan beberapa kerjasama penanganan kebijakan penyelundupan orang (people smugling), dan kerjasama militer. ${ }^{1}$

1 R. Aj. Rizka Februari. Prabanigtyas, S.IP, "Indonesia-Asutralia: Menguji Persahabatan di Tengah Konflik Penyadapan” Institute of International studies Universitas Gadjah Mada, Yogyakarta. Desember 2013. Volume 20 Issue 1, hlm. 2. 
Kedua, meningkatnya ancaman bagi hak-hak kerahasiaan warga negara (individual privacy rights) karena begitu banyak peraturan perundang-undangan di Indonesia yang memberikan ruang bagi penyadapan, bukan hanya pada kejahatan korupsi, narkotika, kejahatan teroris, perdagangan orang, tetapi ruang bagi penyadapan juga ada dalam undang-undang kebebasan memperoleh informasi. Memang praktik penyadapan yang diatur dalam peraturan perundang-undangan terbukti mampu menjadi pencegahan dari kejahatan berat yang berpotensi mengganggu stabilitas dan keamanan negara. Penyadapan yang dilakukan terhadap koruptor membuahkan hal positif dengan adanya beberapa kasus tangkap tangan. Namun, perkembangan peraturan tentang penyadapan ini perlu benar-benar dicermati agar jangan sampai justru mengekang kebebasan HAM warga negara.

\section{Rumusan Masalah}

Bertolak pada kedua kasus tersebut di atas, timbullah tiga persoalan hukum yang perlu jawab. Pertama, bagaimanakah prinsip-prinsip umum dan pengaturan hukum terkait penyadapan dalam hukum dan HAM internasional dan hukum nasional Indonesia? Kedua, mengapa penyadapan sebagai ketentuan hukum khusus (lex specially) tidak dapat dituntut di pengadilan hukum internasional maupun hukum nasional? Ketiga, mengapa tindakan penyadapan yang terjadi antara Australia dan Indonesia tidak dianggap sebagai kejahatan melainkan pelanggaran kode etik diplomasi?

\section{Tujuan Penelitian}

Penelitian ini bertujuan untuk mengetahui: Pertama, prinsip-prinsip umum dan pengaturan hukum terkait penyadapan dalam hukum dan HAM internasional dan hukum nasional Indonesia. Kedua, praktik penyadapan sebagai ketentuan hukum khusus (lex specially) tidak dapat dituntut di pengadilan baik untuk kepentingan hubungan internasional maupun penegakan hukum nasional. Ketiga, tindakan penyadapan Australia terhadap Indonesia bukan sebagai kejahatan melainkan pelanggaran kode etik diplomasi. 


\section{Metode Penelitian}

Penelitian ini didasarkan pada penelitian normatif, dengan menekankan pada pencarian bahan-bahan hukum primer, yaitu pengaturan hukum yang relevan dipergunakan untuk melihat dan menentukan seberapa jauh tindakan penyadapan dapat diberikan pembenaran. Baik dalam hukum HAM internasional, ataupun pengaturan dalam perundang-undangan yang berlaku nasional di Indonesia. Selain itu, dipergunakan bahan-bahan sekunder dan tersier yang bersumber dari buku teks relevan, artikel ataupun karya ilmiah berbentuk fisik ataupun melalui media online.

Hal ini utamanya ditujukan untuk menganalisis kasus merenggangnya hubungan Indonesia-Australia sebagai akibat dari praktik penyadapan yang dilakukan Australia. Namun, penyelesaian hukum menjadi tidak mudah bagi pemerintah Indonesia untuk menuntut secara hukum, mengingat obyek dan kondisi penyadapan di era globalisasi telah berubah menjadi lebih kompleks. Apalagi hampir tiap negara saat ini idak luput untuk melakukan kerjasama intelijen akibat kejahatan terorisme sebagai hostis humanis generis.

\section{Hasil Penelitian dan Pembahasan}

\section{Prinsip-Prinsip Pengaturan tentang Penyadapan}

\section{Prinsip Larangan Penyadapan dalam Hukum dan HAM Internasional}

Istilah penyadapan biasanya dikaitkan dengan kata "interception" atau "wiretapping" dalam bahasa Inggris. Penyadapan secara umum berarti mendengarkan secara rahasia pembicaraan orang lain melalui penyadapan telepon atau intersepsi elektronik lainnya. Amanda Hale menjelaskan bahwa: interception: a person intercepts a communication in the course of its transmission if, as a result of his interference in the system or monitoring of the transmission, some or all of the contents are made available, while being transmitted, to a person other than the sender or the intended recipient of the communication. ${ }^{2}$ hlm. 71 .

2 Amanda Hale and John Edwards, "Getting its Taped”, Computer and Communications Law Review 2006, 
Adapun tentang wiretapping, Jeffrey B. Welty menjelaskan bahwa wiretapping is used to refer to the interception of the context of electronic communications in any format, whether the communication occur via phone, fax email, text messaging, etc. ${ }^{3}$

Dalam khazanah hukum dan HAM internasional, penyadapan secara umum dikategorikan sebagai perbuatan yang dilarang dalam beberapa peraturan. Pertama, Pasal 12 Universal Declaration of Human Right (UDHR) 1948 menjelaskan: No one shall be subjected to arbitrary interference with his privacy, family, home or correspondence, nor to attack upon his honour and reputation. Every one has the right to protection of the law against such interference attacks. Dalam pasal ini jelas bahwa tidak seorangpun boleh diganggu secara sewenang-wenang dalam urusan pribadi, keluarga, rumah tangga atau hubungan surat-menyuratnya, juga tidak boleh dilakukan serangan terhadap kehormatan dan reputasinya. Setiap orang berhak mendapat perlindungan hukum terhadap gangguan atau penyerangan seperti itu.

Kedua, Pasal 17 International Covenant on Civil and Political Right (ICCPR) 1966 menjelaskan: (1). No one shall be subjected to arbitrary or unlawfull interference with his privacy, family, home, correspondence, nor to unlawful attack on his honour and reputation (2). Every one has the right to the protection of the law against such interference or attacks. Maksud dari pasal ini menyebutkan: (1) tidak boleh seorang pun yang dapat secara sewenangwenang atau secara tidak sah dicampuri masalah-masalah pribadinya, keluarganya, rumah atau hubungan surat-menyuratnya, atau secara tidak sah diserang kehormatan dan nama baiknya. (2) setiap orang berhak atas perlindungan hukum terhadap campur tangan atau serangan seperti tersebut di atas.

Ketiga, dalam Komentar Umum No. 16 mengenai Pasal 17 ICCPR yang disepakati oleh Komite Hak Asasi Manusia Perserikatan Bangsa-Bangsa (PBB) pada persidangan ke dua puluh tiga, 1988 yang memberikan komentar terhadap materi muatan Pasal 17 Kovenan Internasional Hak-Hak Sipil dan Politik, pada poin 8 dinyatakan:

"...bahwa integritas dan kerahasiaan korespondensi harus dijamin secara de jure dan de facto. Korespondensi harus diantarkan ke alamat yang dituju tanpa halangan dan tanpa dibuka atau dibaca terlebih dahulu. Pengamatan (surveillance), baik secara

3 Jeffrey B. Welty, "Prosecution and Law Enforcement Access to Information about Electronic Communication”, Administration of Justice Bulletin. 2009/05/October, 2009, hlm. 8. 
elektronik maupun lainnya, penyadapan telepon, telegram, dan bentuk-bentuk komunikasi lainnya, serta perekaman pembicaraan harus dilarang". ${ }^{4}$

Keempat, pada Pasal 8 ayat (1), Konvensi Eropa untuk perlindungan HAM dan Kebebasan Fundamental (1958) menyatakan bahwa "Setiap orang berhak atas penghormatan terhadap kehidupan pribadi atau keluarganya, rumah tangganya dan surat-menyuratnya". ${ }^{5}$

Kelima, larangan penyadapan juga diberlakukan terhadap kantor dan petugas diplomatik. Pasal 27 (1) Konvensi Wina 1961:

The receiving state shall permit and protect free communication and the part of the mission for all official purposes. In communication with the government and the other missions and consulates of sending states, where ever situated, the mission may employ all appropriate. However, the mission may install and use a wireless transmitter only with the consent of the receiving state.

Kemudian pada ayat (2) disebutkan: The official correspondence of the mission shall be inviolable. Official correspondence means all correspondence relating to the mission and its function. Larangan penyadapan bagi korps diplomatik ini berkaitan dengan hak-hak keistimewaan (previllege) dan kekebalan diplomatik (impunity).

Keenam, larangan didasarkan kepada Due Process of Law dijelaskan oleh Tobias dan Petersen: The origin of Due Process of law principle can be traced back at least as far as 1215, when it was part of the Magna Charta in England. The original purpose of the principle was to prevent the crown from acting against an individual that an not under the protection of the law due process of law. Dalam UUD Amerika juga disebutkan bahwa: No person... Be deprived of life, liberty, or property, without due process of law. .. Nor shall any state deprive any person life, liberty, or property without due process of law.

Berdasarkan beberapa kekentuan sebagaimana dijelaskan tersebut, tampak bahwa pada prinsipnya tindakan penyadapan dalam bentuk apapun adalah merupakan pelanggaran terhadap Hak Asasi Manusia. Hukum Internasional menjamin agar tidak seorangpun boleh diganggu secara sewenang-wenang terkait

4 Supriyadi Widodo Eddyono \& Erasmus A. T. Napitupulu. Komentar atas Pengaturan Penyadapan Dalam Rancangan KUHAP. Institue for Criminal Justice Reform. Jakarta. 2013, hlm. 7.

${ }^{5}$ Indonesia Legal Center Publishing, Undang-Undang No. 39 Tabun 1999 tentang Hak. Asasi Manusia, ILCP, Jakarta, 2006, hlm. 119. 
urusan pribadi, keluarga, rumah tangga atau hubungan surat-menyuratnya, juga tidak boleh dilakukan serangan terhadap kehormatan dan reputasinya.

\section{Prinsip Larangan Penyadapan dalam Hukum Nasional}

Di Indonesia, perlindungan atas hak privasi baru dikenal luas setelah amandeman UUD 1945, namun ketentuan yang dapat dirujuk terkait bentuk perlindungan privasi di Indonesia adalah Pasal 551 KUHP. Pasal 551 KUHP menyebutkan bahwa "Barang siapa tanpa wewenang berjalan atau berkendaraan di atas tanah yang oleh pemiliknya dengan cara jelas dilarang memasukinya, diancam dengan pidana denda paling banyak dua ratus dua puluh lima rupiah." 6

Pasca amandemen UUD NRI 1945, hak atas privasi dijamin perlindungannya secara eksplisit dalam berbagai peraturan perundang-undangan dan juga dalam Konstitusi. Pada Pasal 28 G ayat (1) UUD 1945 disebutkan, "Setiap orang berhak atas perlindungan diri pribadi, keluarga, kehormatan, martabat, dan harta benda yang di bawah kekuasaannya, serta berhak atas rasa aman dan perlindungan dari ancaman ketakutan untuk berbuat atau tidak berbuat sesuatu yang merupakan hak asasi".

Pasal 32 UU No. 39 Tahun 1999 tentang Hak Asasi Manusia menyatakan: "Kemerdekaan dan rahasia dalam hubungan surat-menyurat termasuk hubungan komunikasi melalui sarana elektronik tidak boleh diganggu, kecuali atas perintah hakim atau kekuasaan lain yang sah sesuai dengan ketentuan peraturan perundang-undangan"

Pasal 40 UU No. 36 Tahun 1999 tentang Telekomunikasi menyebutkan bahwa: "Setiap orang dilarang melakukan kegiatan penyadapan atas informasi yang disalurkan melalui jaringan telekomunikasi dalam bentuk apapun. Dalam penjelasan Pasal 40 Telekomunikasi disebutkan bahwa, "yang dimaksud dengan penyadapan dalam pasal ini adalah kegiatan memasang alat atau perangkat tambahan pada jaringan telekomunikasi untuk tujuan mendapatkan informasi dengan cara tidak sah. Pada dasarnya informasi yang dimiliki seseorang adalah hak pribadi yang harus dilindungi sehingga penyadapan harus dilarang"

Pasal 31 ayat (1) UU No. 11 Tahun 2008 tentang Informasi dan Transaksi Elektronik menyatakan bahwa "Setiap Orang dengan sengaja dan tanpa hak atau melawan hukum melakukan intersepsi atau penyadapan atas Informasi Elektronik dan/atau

${ }^{6}$ Supriyadi Widodo Eddyono, Op. Cit., hlm. 9 
Dokumen Elektronik dalam suatu Komputer dan/atau Sistem Elektronik tertentu milik Orang lain".

Pasal 31 ayat (2) UU No. 11 Tahun 2008 tentang Informasi dan Transaksi Elektronik disebutkan, "Setiap Orang dengan sengaja dan tanpa hak atau melawan hukum melakukan intersepsi atas transmisi Informasi Elektronik dan/atau Dokumen Elektronik yang tidak bersifat publik dari, ke, dan di dalam suatu Komputer dan/atau Sistem Elektronik tertentu milik Orang lain, baik yang tidak menyebabkan perubahan apa pun maupun yang menyebabkan adanya perubahan, penghilangan, dan/atau penghentian Informasi Elektronik dan/atau Dokumen Elektronik yang sedang ditransmisikan".

Jadi di satu sisi perlindungan privasi telah dijunjung tinggi tidak hanya oleh Konstitusi di Indonesia namun juga dimasukkan dalam berbagai peraturan perudang-undangan. ${ }^{7}$

\section{Penyadapan untuk Kepentingan Penegakan Hukum Kejahatan Luar Biasa dan Kepentingan Negara}

Perkembangan teknologi dan peradaban membawa manusia ke dimensi baru kehidupan, termasuk membawa pada perkembangan kejahatan. Saat ini kejahatan-kejahatan konvensional bergeser motif dan bentuknya mengikuti perkembangan teknologi. Kejahatan-kejahatan seperti korupsi, terorisme, narkotika dan kejahatan-kejahatan serius lainnya tidak dapat lagi dilacak dengan cara-cara konvensional yang dahulu digunakan oleh aparat penegak hukum. Untuk itu aparat penegak hukum perlu mengimbangi kemampuan dari pelakupelaku kejahatan dengan penerapan metode yang lebih efektif dalam menjalankan fungsi penegakan hukumnya. Salah satu metode penanganan dan penanggulangan kejahatan yang muncul adalah Metode Penyadapan. Penyadapan sangat berguna sebagai salah satu metode penyidikan sekaligus sebagai alternatif terbaik dalam investigasi kriminal terhadap perkembangan modus kejahatan dewasa ini. Dengan penyadapan dimungkinkan banyak pelaku kasus-kasus kejahatan berat yang bisa dapat dibawa ke meja atau dicegah sebelum melakukan kejahatan lebih besar. $^{8}$

\footnotetext{
${ }^{7}$ Supriyadi Widodo Eddyono, Op. Cit., hlm. 9-10.

${ }^{8}$ Supriyadi Widodo Eddyono \& Erasmus A. T. Napitupulu, Loc.Cit.
} 
Untuk kepentingan tersebut di atas, meskipun secara prinsipil segala bentuk penyadapan dilarang menurut hukum dan HAM internasional, maka ada beberapa kondisi pengecualian dimana penyadapan bisa dilakukan. Kondisi pengecualian tersebut antara lain diatur dalam Pasal 1 dan 2 dari The International Covenant on Civil and Political Right (ICCPR) 1950 yang menyebutkan:

(1) every one has the right to respect for his privacy and family life, his home, and his correspondence; (2) there shall be no interference by public authority with the exercise of his rights except such as in accordance with the law and is necessary in democratic society in the interest of national security, public safety or the economic well-being of the country, for the prevention disorder or crime, for the protection of health or moral, or for the protection of the rights and freedoms of others.

Berdasarkan bunyi Pasal 1 dan 2 dari ICCPR 1950 di atas dapat ditegaskan bahwa penyadapan yang pada prinsipnya dilarang dapat dikecualikan jika dilakukan untuk hal-hal yang berkaitan dengan a). keamanan nasional, b). keamanan publik atau keamanan ekonomi negara, c). pencegahan kejahatan atau kriminalitas, d). perlindungan kesehatan atau perlindungan moral, serta e). perlindungan hak-hak dan kebebasan orang lain.

Pengecualian terhadap larangan penyadapan juga terjadi sebagai Lex Specially dalam Kejahatan Internasional dalam konteks penanggulangan Kejahatan Pidana Internasional, terutama terkait dengan kejahatan inti (core crime). Kejahatan inti (core crime) tersebut sebagaimana diatur oleh Statuta Roma 1998 menurut William Chabach mencakup: a). kejahatan HAM berat (Gross Violation of Human Rights), b). petnis (genocida/etnic cleansing), berdasarkan pada Newremberg Adhoc Tribunal 1946, c). kejahatan Perang (war crimes), berdasarkan Tokyo Adhoc Tribunal 1948, d). kejahatan Kemanusiaan (crime against humanity), dan e). agresi (the act of aggression). ${ }^{9}$

Pengecualian atas larangan penyadapan dalam ranah hukum pidana internasional selain pada kejahatan inti (core crimes) juga diberlakukan pada Kejahatan Lintas Negara Teroganisir (transnational organized crime) karena temasuk kejahatan luar biasa (extra ordinary crime). Secara rinci kejahatan lintas negara yang

${ }^{9}$ Mengenai Core crime ini dapat dilihat dalam dokumen Rome Statute of the International Criminal Court. Text of the Rome Statute circulated as document A/CONF.183/9 of 17 July 1998 and corrected by processverbaux of 10 November 1998, 12 July 1999, 30 November 1999, 8 May 2000, 17 January 2001 and 16 January 2002. The Statute entered into force on 1 July 2002. 
juga termasuk kejahatan luar biasa (extra ordinary crime), mencakup: a). kejahatan korupsi (corruption crime), b). perdagangan orang (human rafficking), c). pencucian uang (money laundering), d). perdagangan narkotika (illicit drug trafficking), e). penyelundupan senjata (weapon smuggling), dan sebagainya. Pada kasus extra ordinary crime seperti tersebut di atas dimungkinkan dilakukan penyadapan sepanjang ada pengaturan yang jelas dalam peraturan perundangan-undangan negara terkait. ${ }^{10}$

Adapun dalam konteks hukum nasional, sebelum amandemen UUD NRI 1945, perlindungan terhadap hak atas privasi, khususnya yang berupa komunikasi pribadi seseorang diatur di dalam Bab XXVIII KUHP tentang Kejahatan Jabatan terutama di dalam Pasal 433, yang melarang penyadapan telepon dan telegraf secara ilegal. Ketentuan ini kemudian dipertegas dengan lahirnya UU No. 36 Tahun 1999 tentang Telekomunikasi dimana pada Pasal 40 dijelaskan bahwa informasi merupakan bagian dari hak pribadi yang harus dilindungi, oleh karena itu penyadapan harus dilarang. Namun dalam kerangka penegakan hukum, khusus untuk tindak pidana tertentu, yang diancam dengan hukuman di atas 5 tahun, penyadapan informasi sebagai upaya pengungkapan kejahatan dan pengumpulan alat bukti dapat dilakukan sebagai lex specialis. Operator telekomunikasi dalam melakukan penyadapan bersandar pada permintaan tertulis dari Jaksa Agung, Kepala Kepolisian RI, atau penyidik untuk tindak pidana tertentu sebagaimana diatur undang-undang. ${ }^{11}$

Penyadapan dalam kerangka hukum pidana haruslah dilakukan dengan Lawful interception, yang berarti suatu penyadapan dan pengawasan terhadap aktifitas komunikasi harus dilakukan secara sah menurut hukum dan dilakukan oleh lembaga pemerintah yang memiliki kewenangan yang ditentukan oleh peraturan tertentu kepada individu maupun kelompok. Agar suatu penyadapan sah di mata hukum, haruslah didasarkan pada aturan atau perundangan yang mengaturnya dan mengikuti prosedur teknis yang memadai. Apabila aparat penegak hukum melakukan intersepsi tidak berdasarkan pada kaidah hukum yang

${ }^{10}$ Jawahir Thonthowi, "Penyadapan dalam Hukum Internasional dan Implikasinya terhadap Penegakan Hukum Kejahatan Luar Biasa”, makalah, disampaikan dalam acara Studium General di Fakultas Hukum, Universitas Surabaya, Jumat 30 Mei 2014 Kampus UBAYA Surabaya Jawa Timur, hlm. 7.

${ }^{11}$ Lihat Pasal 42 UU No. 36 Tahun 1999 tentang Telekomunikasi 
berlaku dan atas prosedur yang jelas maka akan terjadi penyadapan yang tidak sah (unlawful interception). Implikasi logisnya adalah seluruh barang bukti atau alat bukti digital dari hasil intersepsi tersebut batal demi hukum dan tidak memiliki kekuatan pembuktian dimata hukum. Prinsip-prinsip umum yang terkait dengan lawful interception pernah dituangkan ke dalam the Convention on Cybercrime di Budapest, 23 November 2001.12

Kewenangan dalam melakukan penyadapan hanyalah digunakan terbatas untuk mencegah dan mendeteksi dalam hal kejahatan-kejahatan yang sangat serius dengan syarat: (1) dipergunakan karena metode investigasi kriminal lainnya telah mengalami kegagalan, atau (2) tiada cara lainnya yang dapat digunakan selain penyadapan untuk mendapatkan informasi yang dibutuhkan dan (3) harus ada alasan yang cukup kuat dan dipercaya bahwa dengan penyadapan maka buktibukti baru akan ditemukan dan sekaligus dapat digunakan untuk menghukum pelaku pidana yang disasar. ${ }^{13}$

Di samping itu di beberapa negara, penyadapan dapat juga digunakan dengan dasar kepentingan khusus bagi keamanan negara (interest of national security) dalam rangka penegakan hukum dan stabilitas ekonomi di sebuah negara. Trend ketentuan pembatas penyadapan bagi aparatur negara di berbagai dunia juga telah demikian berkembangan. Penyadapan hanya dapat digunakan dalam kondisi dan prasyarat yang khusus misalnya: (1) adanya otoritas resmi yang jelas berdasarkan UU yang memberikan izin penyadapan (mencakup tujuan yang jelas dan objektif) (2) adanya jaminan jangka waktu yang pasti dalam melakukan penyadapan (3) pembatasan penanganan materi hasil penyadapan (4) pembatasan mengenai orang yang dapat mengakses penyadapan dan pembatasan-pembatasan lainnya. ${ }^{14}$

Saat ini yang masih disayangkan adalah ketiadaan aturan tunggal tentang tata cara penyadapan di Indonesia menyebabkan kerentanan terhadap tindakan intersepsi komunikasi pribadi warga negara, termasuk komunikasi menggunakan internet, seperti surat elektronik serta bermacam perangkat media sosial. Sampai

\footnotetext{
12 Supriyadi Widodo Eddyono, Op. Cit., hlm. 4.

${ }^{13}$ Ibid.

${ }^{14}$ Ibid.
} 
hari ini, Indonesia sedikitnya memiliki 12 undang-undang, 2 Peraturan Pemerintah, 2 Peraturan Meteri, 1 Peraturan Kapolri, dan 1 Peraturan berupa SOP (Standar Oprasional Prosedur) yang di dalamnya mengatur tentang penyadapan/intersepsi komunikasi dengan tata cara yang berbeda-beda. ${ }^{15}$ Perbedaan pengaturan mengenai penyadapan ini misalnya nampak sangat nyata antara UU Pemberantasan Tindak Pidana Terorisme, UU Narkotika, UU Komisi Pemberantasan Tindak Pidana Korupsi, dan UU Intelijen Negara. ${ }^{16}$

Dalam konteks keamanan nasional, secara prinsipil institusi keamanan, khususnya intelijen memang sudah sepatutnya memiliki kewenangan dan kemampuan untuk melakukan pengamatan/surveillance dan intersepsi komunikasi, sebagai bagian dari cara pengumpulan informasi. Namun demikian, undang-undang nasional harus secara tegas mengatur mengenai hal-hal berikut ini: ${ }^{17}$ (1) tindakan intersepsi yang dapat dilakukan, (2) tujuan melakukan intersepsi, (3) kategorisasi objek individu yang dapat dilakukan intersepsi, (4) ambang kecurigaan bukti permulaan, yang diperlukan untuk membenarkan penggunaan tindakan intersepsi, (5) pengaturan mengenai pembatasan durasi dalam melakukan tindakan intersepsi, (6) prosedur otorisasi perijinan, dan (7) pengawasan serta peninjauan atas tindakan intersepsi yang dilakukan. Bagaimanapun perlindungan hak atas privasi warga negara tetap harus menjadi perhatian utama di dalam setiap pembentukan kebijakan dan aktivitas pertahanan yang memanfaatkan teknologi informasi dan komunikasi.

\section{Kasus Penyadapan dalam Praktek Diplomasi Antar Negara Dewasa Ini}

Kasus penyadapan yang melibatkan hubungan antar negara bukanlah barang baru dalam dunia intelejen. Meskipun pada prinsipnya penyadapan adalah tindakan ilegal dan dianggap sebagai kejahatan terhadap HAM, namun dalam

15 Ibid., hlm. 13.

16 Wahyudi Djafar, "Protecting Privacy Rights from Wiretapping", The Jakarta Post, 21 Februari 2013, dapat diakses di http://www.thejakartapost.com/news/2013/02/21/protecting-privacy-rights-wiretapping.html. Lihat Laporan Pelapor Khusus PBB untuk kebebasan berekspresi dan berpendapat, Frank La Rue, A/HRC/23/40, dapat diakses dalam website http://www.ohchr.org/Documents/HRBodies/HRCouncil /RegularSession/Session23/A.HRC.23.40_EN.pdf, diakses tanggal Rabu, 28 Mei 2014.

${ }_{17}$ Martin Scheinin, Compilation of Good Practices on Legal and Institutional Frameworks and Measures that Ensure Respect for Human Rights by Intelligence Agencies while Countering Terrorism, including on their Oversight, (UN Human Rights Council, 2010), hlm. 19. 
perkembangannya dalam kontek perilaku hubungan antara negara, penyadapan tampaknya telah bergeser makna tidak lagi sebagai kejahatan melainkan lebih merupakan pelanggaran kode etik diplomatik karena tidak ada lagi unsur pelanggaran territorial di mana penyadap harus menerobos masuk ke wilayah negara lain secara illegal untuk memasang perangkat spionase. Negara yang terlibat dalam kasus penyadapan lintas negara saat ini juga tidak ada satu pun yang membawa persoalan penyadapan tersebut ke Pengadilan Internasional. Hal ini mungkin karena faktor globalization is used as a wave of information technology, yang berakibat batas kedaulatan negara-negara menjadi borderless.

Dahulu penyadapan dilakukan dengan memasukkan secara ilegal alat-alat dan perlengkapan spionase ke area gedung perwakilan diplomatik dan konsuler seperti tape recorder, spy camera, atau menambahkan alat-alat tertentu pada perangkat telepon atau telegram di gedung perwakilan diplomatik dan konsuler negara lain. Hal ini dimaksudkan untuk mendengarkan secara rahasia pembicaraan orang lain melalui penyadapan, melakukan intersepsi elektronik atau merekam peristiwa secara ilegal. Sebagai contoh adalah penyadapan yang dilakukan Myanmar pada KBRI di Yangoon dimana junta militer Myanmar telah dengan sengaja memasang alat penyadap pada dinding kamar kerja Duta Besar RI untuk Myanmar sehingga terjadi penurunan frekuensi dari 50MHz menjadi 30,1MHz. ${ }^{18}$

Pada saat ini penyadapan atau pencurian informasi diplomatik dapat dilakukan dengan peralatan canggih tanpa harus ada tindakan pelanggaran masuk ke dalam gedung diplomatik dan konsuler atau ke wilayah negara lain. Dengan bantuan teknologi satelit yang bisa menjangkau seluruh wilayah di dunia, negaranegara super power mampu mendapatkan informasi dan data-data akurat tanpa harus menyusupkan berbagai peralatan spionase ke territorial negara lain. Negaranegara yang memiliki teknologi satelit di wilayah luar angkasa memiliki kemampuan mendeteksi sesuatu yang dulu dirahasiakan oleh suatu negara akan tetapi saat ini telah menjadi sesuatu yang bukan rahasiah lagi (disclosed matters). Dengan teknologi canggih berbasis satelit tersebut maka pihak penyadap tidak

\footnotetext{
18 Dewa Gede Sudika Mangku. "Pelanggaran terhadap Hak Kekebalan Diplomatik: Studi Kasus Penyadapan KBRI di Yangoon Myanmar Berdasarkan Konvensi Wina Tahun 1961”, Jurnal Perspektif Volume XV No. 3 Tahun 2010, Edisi Juli, hlm. 228-229.
} 
perlu lagi harus melakukan tindakan memasukkan secara ilegal alat-alat dan perlengkapan spionase ke area gedung perwakilan diplomatik dan konsuler maupun masuk ke teritorial wilayah negara lain. Akibatnya, status penyadapan semacam ini sangat sulit untuk di tuntut sebagai tindakan kejahatan dan hanya dianggap sebagai pelanggaran etika diplomasi semata.

Sebuah kasus menarik tentang penyadapan yang berkaitan dengan hubungan diplomasi antar negara adalah kasus penjebolan dan penyebarluasan data-data intelejen oleh Edward Snowden. Karena pengaturan pada penyadapan model ini umumnya diatur dalam Konvensi Wina 1961, terkait dengan diplomasi, maka kedudukan negara-negara yang tersadap sebagai akibat penjebolan dan penyebarluasan data-data intelejen oleh Edward Snowden tidak mudah untuk menuntut negara pelaku mengingat sudah keluar dari ranah hukum karena ada previlieges, imunity dan inviolability bagi korp diplomatik. ${ }^{19}$

Terkait penyebarluasan data-data intelejen oleh Edward Snowden, Presiden AS, Barrack Obama, telah menyampaikan pemohonan maaf kepada semua pihak terkait, setalah diketahui bahwa staf CIA Amerika telah melakukan penyadapan terhadap pimpinan negara-negara Eropa seperti Jerman, Perancis, Italia, dan Spanyol. Kanselir Jerman, Anggela Markel, dan para pemimpin Uni Eropa termasuk petinggi Jerman, Perancis, Italia dan Spanyol juga melakukan nota protes terhadap AS. Bahkan duta besar AS dipanggil oleh Pemerintah Jerman di Berlin untuk melakukan klarifikasi lebih jauh.

Pemerintah negara-negara Eropa mengetahui, bahwa data-data penyadapan itu juga dikirimkan ke Dinas Intelejen AS, utamanya terkait dengan data rahasia teroris. Tetapi mereka tidak satupun yang membawa kasus ini ke pengadilan internasional mengingat pengumpulan data intelejen baik itu terangterangan ataupun rahasia sudah menjadi bagian utama seluruh pemerintah Barat, terlepas apakah pemerintahan ini di luar gencar menampilkan diri sebaga pembela HAM atupun mengklaim sebagai pihak yang menjaga privasi seseorang dan mendukung kebebasan berpendapat. ${ }^{20}$

${ }^{19}$ Tidak Sekali Ini Saja Australia Cederai Indonesia, http://www.jurnalparlemen.com/view/7073/tidaksekali-austr.d iakses Rabu, 28 Mei 2014.

${ }^{20}$ Jawahir Thonthowi, Loc. Cit., 
Terkait bocoran dari Edward Snowden ini ada juga fakta bahwa intelejen negara Australia telah melakukan penyadapan terhadap beberapa pejabat negara Republik Indonesia, termasuk Ibu negara Ani Yudhoyono, Menterian Ekonomi, juga Menteri Pertahanan saat itu. Tetapi penyelesaian kasus penyadapan ini secara diplomatis tidak semulus yang terjadi antara pemerintah AS di bawah Barrak Obama dengan negara-negara Uni Eropa. Hal ini disebabkan keengganan pihak Australia mengakui dan meminta maaf kepada Indonesia sebagai negara yang dirugikan.

Pada saat Tony Abbott berkunjung ke Indonesia, sekitar akhir 2013, Prokontra sekitar tudingan penyadapan membuat hubungan kedua negara terlibat dalam ketegangan hubungan diplomatik. Beberapa pakar hukum internasional, Hikamahanto Juawana, juga beberapa anggota DPR RI mendesak agar SBY memutuskan hubungan diplomatik dengan Australia. Mempertimbangkan berbagai masukan tersebut memang SBY tidak memutuskan hubungan diplomatik dengan Australia. Namun SBY segera menarik sementara Duta Besar Indonesia dari Canbera dan mebatalkan beberapa kerjasama penanganan kebijakan penyelundupan orang (people smugling), dan kerjasama militer. Begitu pula, Tony Abbott juga tidak menyampaikan permohonan maaf, atas sesuatu kesalahan yang tidak pernah ia kerjakan karena kejadian tersebut timbul 2009, sementara dia dilantik sebagai Perdana Menteri 2013.21

Dalam menanggapi isu bocornya penyadapan yang dilakukan oleh Australia Menteri Luar Negeri Indonesia memberikan respon dengan melakukan jumpa pers sehari setelah merebaknya pemberitaan mengenai penyadapan tersebut di media-media internasional. Dalam jumpa pers tersebut Menteri Luar negeri menyatakan tidak terima atas sikap dan alasan penyadapan yang dilakukan oleh Australia. Pernyataan Menlu Marty juga dibarengi dengan langkah konkrit, salah satunya adalah pemanggilan Kuasa Usaha Ad Interim Kedubes Australia di Jakarta dan pembahasan bersama pihak Kemenlu Australia beberapa waktu lalu di India.22 Duta Besar Indonesia di Canberra juga turut dipanggil ke Jakarta untuk

${ }^{21}$ R. Aj. Rizka Februari. Prabanigtyas, Indonesia-Asutralia: Menguji Persahabatan di Tengah Konflik Penyadapan. Institute of International studies Universitas Gadjah Mada, Yogyakarta. Desember 2013. Volume 20 Issue 1, hlm. 3-4. 22 Menlu RI: Kami Tidak Terima Alasan Penyadapan Australia http://www.deplu.go.id/Pages/News.aspx?IDP=6627\&l=id Diakses Rabu, 28 Mei 2014. 
konsolidasi lebih lanjut. Pemanggilan Duta Besar Indonesia di Canberra untuk mengadakan konsultasi menyangkut perkembangan terkini. Selain dalam rangka konsultasi, pemanggilan dilakukan sebagai langkah mengkaji ulang kerjasama bilateral kedua negara khususnya di bidang informasi dan tukar-menukar intelijen antara Indonesia dan Australia. Begitupula dengan Duta Besar Australia, Greg Moriarty telah diminta datang ke Kementerian Luar Negeri pada 1 Nopember 2013 untuk dimintakan penjelasan resmi dari Pemerintah Australia terhadap kebenaran pemberitaan di surat kabar harian Sydney Morning Herald pada 31 Oktober 2013 tentang keberadaan dan penggunaan fasilitas penyadapan di Kedutaan Australia di Jakarta dan negara-negara lain di kawasan. ${ }^{23}$

Seiring dengan respon yang diberikan oleh Menteri Luar Negeri, Pemerintah pusat juga memastikan untuk mengevaluasi hubungan dengan Australia apabila masalah penyadapan tidak segera diselesaikan dan Presiden Susilo Bambang Yudhoyono menggarisbawahi tiga hal yang akan dilakukan Indonesia terkait penyadapan tersebut. Pertama, Indonesia menunggu penjelasan resmi Australia kepada Indonesia, bukan pada komunitas di Australia. Kedua, terkait kasus penyadapan itu terhadap Presiden Republik Indonesia dan pejabat Indonesia, dua hari lalu ada sejumlah agenda kerja sama yang dilakukan Indonesia dengan Australia, diminta untuk dihentikan. Kerja sama yang disebut pertukaran informasi dan pertukaran intelijen di antara dua negara untuk sementara dihentikan. Juga latihan-latihan bersama antara tentara Indonesia dan Australia baik Angkatan Darat, Angkatan Laut, Angkatan Udara dan Polri. ${ }^{24}$

Penghentian itu juga berlaku pada Coordinated Military Operation antara Indonesia-Australia untuk menghadapi permasalahan bersama yang merepotkan kedua negara. Panglima TNI Jenderal Moeldoko menegaskan, Indonesia menghentikan seluruh latihan militer gabungan dengan Australia mulai Rabu 20 November 2013. Ketiga, Indonesia berpendapat dan meminta keberlanjutan kerja sama di masa depan, memerlukan semacam protokol atau Code of Conduct,

\footnotetext{
23 Indonesia Tuntut Penjelasan Terkait Berita Fasilitas Penyadapan Kedubes Australia di Jakarta http://www.kemlu.go.id/bandarseribegawan/Pages/News.aspx?IDP=6581\&l=id Diakses Rabu, 28 Mei 2014.

24 Buntut Penyadapan, RI Evaluasi Hubungan Diplomatik dengan Australia http:/ / metrobali.com/2013/11/22/buntut-penyadapan-ri-evaluasi-hubungan-diplomatik-dengan-australia/ Diakses Rabu, 28 Mei 2014.
} 
sekaligus Guiding Principal (panduan utama) menyangkut kerja sama di berbagai bidang, termasuk Latihan Bersama Indonesia-Australia dalam menghadapi ancaman penyelundupan manusia, kerjasama pertukaran intelijen dan informasi. Menko Politik Hukum dan Keamanan Djoko Suyanto menegaskan, isu penyadapan terhadap Presiden dan beberapa orang terdekatnya oleh Australia akan berdampak terhadap hubungan bilateral Indonesia-Australia. Kementerian Luar Negeri akan meminta Australia untuk menyampaikan pernyataan publik guna mengklarifikasi berita aktivitas penyadapan tersebut. Pemerintah Indonesia juga akan mempertimbangkan kembali berbagai kerja sama yang telah dijalin antara kedua negara termasuk pertukaran informasi dan penempatan pejabat Australia di Kedubes Australia di Jakarta.

Pemerintahan Australia melalui Perdana Menteri Tony Abbott akhirnya menolak meminta maaf atas tuduhan penyadapan yang dilakukan Australia terhadap pejabat Indonesia, dan meminta semua pihak untuk berkepala dingin dalam masalah ini. Pernyataan Tony Abbott disampaikan dalam sidang di Parlemen Australia Selasa 19 November 2013. Tony Abbot mengatakan, pemerintahan "mengumpulkan informasi" dan setiap pemerintah tahu bahwa pemerintah lainnya mengumpulkan informasi. Selain menolak meminta maaf kepada pemerintah Indonesia, Australia juga mengeluarkan travel advisory agar warganya menunda kunjungan ke Indonesia selama kondisi hubungan bilateral kedua negara masih belum stabil. Menteri Luar Negeri Indonesia menyatakan akan terus memastikan langkah-langkah yang akan diambil selanjutnya bila pihak Australia tidak segera menyelesaikan kasus tersebut. Indonesia juga tengah mengevaluasi untuk terus menurunkan derajat kerja sama antar kedua negara. Hal ini bisa menjadi alternatif pertimbangan bagi pemerintah kita, karena jika penarikan Dubes dari Canberra hanya ditanggapi dingin oleh pihak Australia, maka apabila menurunkan level hubungan diplomatik Indonesia-Australia ketingkat yang lebih rendah. Di antaranya menjadikan KBRI Canberra sebagai setingkat Konsulat Jenderal atau Konjen. Dengan tindakan diplomatik seperti ini secara tidak langsung ada "punishment" dari Indonesia kepada Australia tanpa harus khawatir akan keberlangsungan kepentingan ekonomi Indonesia di Australia.

Berdasarkan dua kasus di atas, dalam kontek perilaku hubungan antara negara, penyadapan tampaknya telah bergeser makna tidak lagi sebagai kejahatan 
melainkan lebih merupakan pelanggaran kode etik diplomatik. Kemarahan Jerman, Perancis, Italia, Spanyol, Indonesia terhadap Amerika Serikat dan juga Indonesia terhadap Australia lebih dituangkan dalam bentuk tekanan-tekanan diplomatik dan pemaafan. Negara yang terlibat dalam kasus penyadapan lintas negara juga tidak ada satu pun yang membawa persoalan penyadapan tersebut ke Pengadilan Internasional.

\section{Penutup}

Penelitian ini menyimpulkan sebagai berikut. Pertama, secara juridis penyadapan merupakan perbuatan dilarang dalam hukum dan HAM internasional berdasarkan Pasal 12 Universal Declaration of Human Right (UDHR) 1948, Pasal 17 International Covenant on Civil and Political Right (ICCPR) 1966. Komite Hak Asasi Manusia Perserikatan Bangsa-Bangsa (PBB) pada persidangan ke dua puluh tiga Tahun 1988, melarang praktek penyadapan sebagaimana diatur terhadap kantor dan petugas diplomatik. Larangan tersebut juga ada dalam Pasal 8 ayat (1), Konvensi Eropa untuk perlindungan HAM dan Kebebasan Fundamental (1958) dan Pasal 27 (1) Konvensi Wina 1961 terkait larangan penyadapan terhadap kantor dan petugas diplomatik, serta larangan terkait Due Process of Law, baik bagi hakhak rahasia individu (basic fundamental rights) maupun hak-hak imunitas bagi korp diplomatik. Dalam kerangka hukum nasional, pelarangan penyadapan termaktub dalam Pasal 28 G ayat (1) UUD 1945, Pasal 32 UU No. 39 Tahun 1999 tentang Hak Asasi Manusia, Pasal 40 UU No 36 Tahun 1999 tentang Telekomunikasi, Pasal 31 ayat (1) UU No. 11 Tahun 2008 tentang Informasi dan Transaksi Elektronik, dan Pasal 31 ayat (2) UU No. 11 Tahun 2008 tenang Informasi dan Transaksi Elektronik.

Kedua, larangan penyadapan dalam hukum pidana internasional bisa diperkecualikan untuk khususnya kejahatan sebagaimana diatur Statuta Roma 1998, dan Kejahatan Lintas Negara Teroganisir, seperti korupsi, kejahatan narkotik, terorisme, pencucian uang, dimungkinkan dilakukan sepanjang jelas pengaturan dalam peraturan perundangan-undangannya suatu negara. Dalam hukum nasional pun ada peraturan khusus yang menjadikan penyadapan diperbolehkan pada suatu keadaan mengancam ketertiban dan keamanan negara. Penyadapan hanya bisa 
dilakukan dengan pemenuhan syarat-syarat yang berat dan ketat dan tata caranya diatur undang-undang. Indonesia memiliki banyak peraturan perundang-undangan yang di dalamnya mengatur tentang penyadapan/intersepsi komunikasi dengan tata cara yang berbeda-beda, antara lain yaitu UU Pemberantasan Tindak Pidana Terorisme, UU Narkotika, UU Komisi Pemberantaras Tindak Pidana Korupsi, dan UU Intelijen Negara.

Ketiga, dalam konteks perilaku hubungan antara negara, penyadapan sebagaimana yang dilakukan Australia terhadap Indonesia tampaknya telah bergeser makna tidak lagi sebagai kejahatan melainkan lebih merupakan pelanggaran kode eitk diplomatik. Kasus keberatan Jerman, Perancis, Italia, Spanyol, dan Indonesia terhadap Amerika Serikat dan juga Indonesia terhadap Australia lebih dituangkan dalam sikap diplomatik dan pemaafan. Beberapa faktor pengaruh seperti globalisasi teknologi informasi, munculnya prinsip-prinsip baru dalam hukum HAM dan Pidana Internasional, kerjasama negara terkait intelejen, dan juga bantuan kemanusiaan antara negara menciptakan negara-negara tidak mudah mengklaim bahwa penyadapan sebagai kejahatan yang dapat diselesaikan di pengadilan internasional.

\section{Daftar Pustaka}

B. Welty, Jeffrey, Prosecution and Law Enforcement Access to Information about Electronic Communication, Administration of Justice Bulletin, 2009/05/October, 2009.

Djafar, Wahyudi, Protecting Privacy Rights from Wiretapping, The Jakarta Post, Tanggal 21 Februari 2013, dapat diakses di http:/ / www.thejakartapost.com/news/2013/02/21/protectingprivacy-rights-wiretapping.html. Lihat Laporan Pelapor Khusus PBB untuk kebebasan berekspresi dan berpendapat, Frank La Rue, A/HRC/23/40, dapat diakses dalam website http://www.ohchr.org/Documents/HRBodies/HRCouncil/Regular Session/Session23/A.HRC.23.40_EN.pdf, diakses Rabu, 28 Mei 2014.

Gede Sudika Mangku, Dewa, "Pelanggaran terhadap Hak Kekebalan Diplomatik: Studi Kasus Penyadapan KBRI di Yangoon Myanmar Berdasarkan Konvensi Wina Tahun 1961", Jurnal Perspektif Volume XV No. 3 Tahun 2010, Edisi Juli. 
Hale, Amanda and John Edwards, "Getting its Taped", Computer and Communications Law Review 2006.

Indonesia Legal Center Publishing, Undang-Undang No.39 Tahun 1999 tentang Hak Asasi Manusia, ILCP, Jakarta, 2006.

Masyhur Effendi, A., Hukum Konsuler-Hukum Diplomatik Serta Hak dan Kewajiban Wakil-wakil Organisasi Internasional/Negara, IKIP Malang, 1994.

Rizka Februari, R. Aj. Prabanigtyas, Indonesia-Asutralia: Menguji Persahabatan di Tengah Konflik Penyadapan. Institute of International studies Universitas Gadjah Mada, Yogyakarta, Desember 2013. Volume 20 Issue 1.

Rome Statute of the International Criminal Court. Text of the Rome Statute circulated as document A/CONF.183/9 of 17 July 1998 and corrected by process-verbaux of 10 November 1998, 12 July 1999, 30 November 1999, 8 May 2000, 17 January 2001 and 16 January 2002. The Statute entered into force on 1 July 2002.

Setiawan, Arif, Penyadapan dalam Perspektif Due Process of Law. Makalah terbatas FGD, FH Universitas Islam Indonesia, 28 Mei 2014.

Suryono, Edi, Hukum Diplomatik Kekebalan dan Keistimewaannya, Angkasa, Bandung, 1991.

Thonthowi, Jawahir, Penyadapan dalam Hukum internasional dan Implikasinya terhadap Penegakan Hukum Kejahatan Luar Biasa. Disampaikan dalam acara Studium General di Fakultas Hukum, Universitas Surabaya, Jumat 30 Mei 2014 Kampus UBAYA Surabaya Jawa timur.

Widodo Eddyono, Supriyadi \& Erasmus A. T. Napitupulu. Komentar atas Pengaturan penyadapan dalam Rancangan KUHAP, Institue for Criminal Justice Reform, Jakarta, 2013.

Konvensi Wina Tahun 1961 tentang Hubungan Diplomatik.

UUD Republik Indonesia 1945.

Universal Declaration of Human Right (UDHR) 1948.

International Covenant on Civil and Political Right (ICCPR) 1966.

UU No. 39 Tahun 1999 tentang Hak Asasi Manusia

UU No 36 Tahun 1999 tentang Telekomunikasi

UU No. 11 Tahun 2008 tentang Informasi dan Transaksi Elektronik

Tidak Sekali Ini Saja Australia Cederai Indonesia, http://www.jurnalparlemen. com/view/7073/tidak-sekali-austr... Diakses Rabu, 28 Mei 2014.

Menlu RI: Kami Tidak Terima Alasan Penyadapan Australia http://www.deplu.go.id/Pages/News.aspx?IDP=6627\&l=id Diakses Rabu, 28 Mei 2014. 